\title{
Correction to: Stigma for common mental disorders in racial minorities and majorities a systematic review and meta-analysis
}

Ozlem Eylem ${ }^{1,2^{*}}$, Leonore de Wit ${ }^{1}$, Annemieke van Straten ${ }^{1}$, Lena Steubl ${ }^{3}$, Zaneta Melissourgaki ${ }^{4}$, Gözde Topgüloğlu Danışman ${ }^{5}$, Ralph de Vries ${ }^{6}$, Ad J. F. M. Kerkhof ${ }^{1}$, Kamaldeep Bhui $^{2}$ and Pim Cuijpers ${ }^{1}$

\section{Correction to: BMC Public Health 20, 879 (2020) https://doi.org/10.1186/s12889-020-08964-3}

It was highlighted that in the original article [1] Table 4 contained an error in its formatting. This Correction article shows the correct Table 4. The original article has been updated.

\begin{abstract}
Author details
'Department of Clinical, Neuro and Developmental Psychology, Amsterdam Public Health Research Institute, Vrije Universiteit Amsterdam, Van der Boechorststraat 1, 1081 BT Amsterdam, The Netherlands. ${ }^{2}$ Centre for Psychiatry, Queen Mary University of London, London, UK. ${ }^{3}$ Department of Clinical Psychology and Psychotherapy, University of UIm, Ulm, Germany. ${ }^{4}$ Department of Psychology, University of Warwick, Coventry, UK. ${ }^{5}$ Faculty of Social Sciences, Centre for Family and Couple Therapy, Özyeğin University, Istanbul, Turkey. ${ }^{6}$ Medical Library, Vrije Universiteit, Amsterdam, the Netherlands.
\end{abstract}

Published online: 01 September 2020

\section{Reference}

1. Eylem, et al. Stigma for common mental disorders in racial minorities and majorities a systematic review and meta-analysis. BMC Public Health. 2020; 20:879. https://doi.org/10.1186/s12889-020-08964-3.

The original article can be found online at https://doi.org/10.1186/s12889020-08964-3.

* Correspondence: o.eylem@vu.nl

'Department of Clinical, Neuro and Developmental Psychology, Amsterdam Public Health Research Institute, Vrije Universiteit Amsterdam, Van der Boechorststraat 1, 1081 BT Amsterdam, The Netherlands ${ }^{2}$ Centre for Psychiatry, Queen Mary University of London, London, UK

Full list of author information is available at the end of the article

(c) The Author(s). 2020 Open Access This article is licensed under a Creative Commons Attribution 4.0 International License, which permits use, sharing, adaptation, distribution and reproduction in any medium or format, as long as you give appropriate credit to the original author(s) and the source, provide a link to the Creative Commons licence, and indicate if changes were made. The images or other third party material in this article are included in the article's Creative Commons licence, unless indicated otherwise in a credit line to the material. If material is not included in the article's Creative Commons licence and your intended use is not permitted by statutory regulation or exceeds the permitted use, you will need to obtain permission directly from the copyright holder. To view a copy of this licence, visit http://creativecommons.org/licenses/by/4.0/ The Creative Commons Public Domain Dedication waiver (http://creativecommons.org/publicdomain/zero/1.0/) applies to the data made available in this article, unless otherwise stated in a credit line to the data. 
Table 4 Stigma for CMDs between racial minorities and majorities: Effect sizes of primary outcomes in all studies

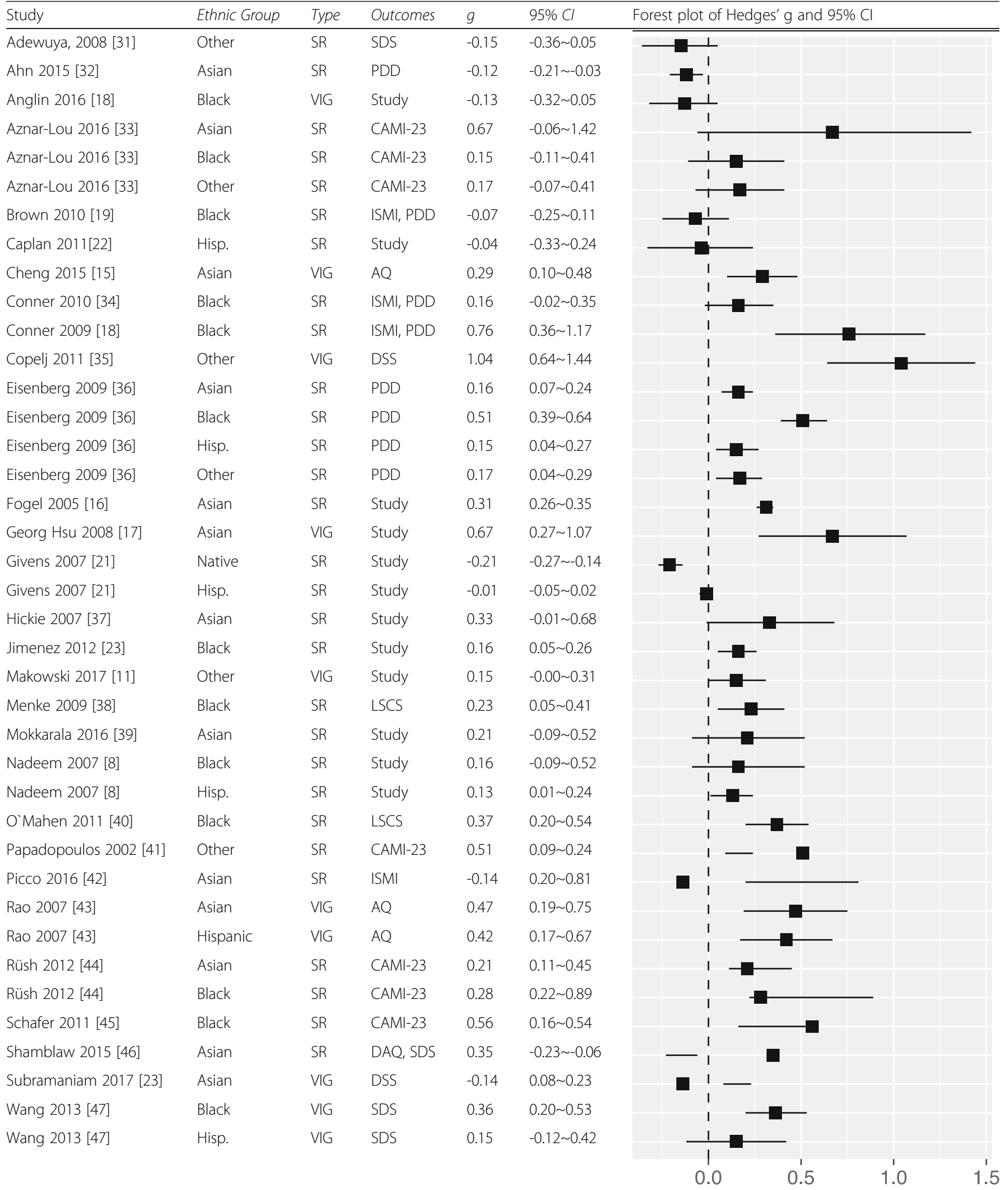

